\title{
The Effect of Acquisition on Income Statement Items in Acquired Company (Subsidiary Company) - Case Study
}

\author{
Mohammad Ali Al Hayek ${ }^{1}$ \\ ${ }^{1}$ Accounting Department, Al al.Bayt University, Jordan \\ Correspondence: Mohammad Ali Al Hayek, Accounting Department, Al al.Bayt University, Jordan. E-mail: \\ mhayek30@yahoo.com
}

Received: March 10, 2018

Accepted: April 6, 2018

Online Published: April 15, 2018

doi:10.5539/ijef.v10n5p173

URL: https://doi.org/10.5539/ijef.v10n5p173

\begin{abstract}
The current study aimed at identifying the effect of acquisition on income statement items in acquired company (subsidiary company), a case study of Irbid Electricity (IDECO). In order to achieve this objective, the researcher has carried out an analytical study that applied the descriptive analytical approach, using the necessary scientific knowledge on the different aspects of the study by reference to the previous studies and the scientific references, the use of the statistical approach to analyze the study data represented by the actual data taken from Irbid Electricity (IDECO) for the period (2002-2016). The results of the study showed statistically significant differences in energy sales average, energy purchase cost, other operating revenues, other revenues, operating expenses, and earning per share before and after acquisition, and also, the results have shown no significant differences between the average of other expenses before and after acquisition. The most important recommendations of the study were the necessity of taking advantage of the experiences of acquisitions and thinking of it seriously, working to raise awareness of the importance of acquisition and clarify its positive effects, and to benefit from global experiences in the acquisition and its positive impact.
\end{abstract}

Keywords: acquisition, holding company, subsidiary company, Irbid Electricity (IDECO)

\section{Introduction}

Shareholders always expect that the Company's management to increase the value of equity by increasing their profits. This objective is achieved either through the internal expansion of the company's business and activities or through external expansion, which is usually represented by an acquisition of another entity .Acquisition is one of the most important issues in the accounting and financial areas. In the modern economics, acquisition is a very important station for strengthening economies and financial sectors. The acquisition is a requirement for the development process as it contributes to the growth and economic expansion opportunities as well as developments in the areas of information and technology, heading towards large economic blocs, which calls for the formation of strong units able to compete and continue in the market. Also, acquisition is used in many cases to get out of the crises of deficit and bankruptcy that may be faced by a facility. The motive towards traditional acquisition was the desire to monopolize the market, but this motive has become rejected by law in most legislations, so as to protect consumers, and to prevent the control of capital, while other positive motives for the acquisition has become the one of the familiar long-term investment aspects, with different motives such as expansion or ensuring the continued flow of some raw materials from the subsidiary to the holding company. The acquisition is realized through the acquisition of whole or more than $50 \%$ of the acquired company's shares and the formation of the so-called holding company and the subsidiary company (Al-Qadi, 2017) and achieving the control over such subsidiary company by owning the majority of the company's general assembly' votes (Dabbas, 2012), then the effective participation in management by the membership of the General assembly, and controlling and the subsidiary in the interests of the Holding Company (Al-Qadi, 2017).

The current study aimed at identifying the effect of acquisition on income statement items in acquired company (subsidiary company), a case study of Irbid Electricity (IDECO) which is one of the major companies in the services sector, which is a subsidiary of the Electricity Distribution Company (EDCO) (a holding company), which owns a total of (4436800 shares) out of 8 million shares, representing $(55.46 \%)$ of them. The nominal value per share is one JD (Irbid Electricity (IDECO), 2018). 


\subsection{Study Problem}

The acquisition of financial accounting's point of view is considered as a long-term investment tool and external expansion to increase the value of equity by increasing the generated profits in addition to other positive motives that benefit the holding subsidiary companies. The study problem lies in the following question: "Is there an effect of acquisition on the income statement items of the acquired company?", and the following sub-questions arise: "Is there an effect of acquisition on energy sales, energy purchase cost, other operating revenues, other revenues, operating expenses, other expenses, earning per share of the acquired company?".

\subsection{Importance of the Study}

The importance of the current study lies in that the issue of acquisition is important in the fields of accounting and finance, and it is considered as a long-term investment tool that contributes to the promotion of opportunities for growth and external expansion and the generation of profits, which gives special importance to the subject of research in terms of determining the impact of acquisition on the elements of the income statement (energy sales, energy purchase cost, other operating revenues, other revenues, operating expenses, other expenses, earning per share) in the acquired company (subsidiary).

\subsection{Hypotheses of the Study}

The researcher has relied on the following main hypothesis to achieve the objectives of the study:

H0: There is an effect of acquisition on income statement items in acquired company (subsidiary company), a case study of Irbid Electricity (IDECO).

The following sub-hypotheses were derived from the main hypothesis:

H01: There is an effect of acquisition on energy sales average of the acquired company (subsidiary).

H02: There is an effect of acquisition on energy purchase cost of the acquired company (subsidiary).

H03: There is an effect of acquisition on the other operating revenues of the acquired company (subsidiary).

H04: There is an effect of acquisition on the operating expenses of the acquired company (subsidiary).

H05: There is an effect of acquisition on the other revenues of the acquired company (subsidiary).

H06: There is an effect of acquisition on other expenses in the acquired company (subsidiary).

H07: There is an effect of acquisition on earning per share in the acquired company (subsidiary).

\subsection{Previous Studies}

Al- Hayek (2015) studied the effect of mergers between Jordanian public shareholding companies in their shares; particularly the effect of legal merger and Consolidation, but did not mention the third type (control). The researcher has used the indicators (volume of shares exchange, number of shares exchanged, number of transactions, market value per share, book value per share earnings per share, dividends per share, stock yield), to identify the impact of legal merger and consolidation. A sample of the merger and consolidation cases that took place during the period of the study (2003-2013) was taken. The study sample consisted of 12 cases. The study has revealed a number of results, the most important of which were: There was an effect of legal merger on the variables: market value per share, book value per share and earnings per share, dividends per share and stock yield, and an effect of consolidation on the variables: volume of shares exchange, market value per share, book value per share, earnings per share and dividends per share.

Kwazhi and Kumshe (2015) have studied the effects of mergers and acquisitions on the distribution of profits and the share of selected deposit prices in Nigeria, where companies rely on mergers and acquisitions as a strategy to enhance profitability and to increase share rate and ordinary dividends to shareholders. In order to achieve the objectives of the study, the researchers have applied the analytical descriptive approach to examine the relationship between after - tax profit and the dividends in the selected banks. The statistical analysis showed a significant relationship between after - tax profit and dividends, and there was a significant difference between share rate before and after the banks' acquisition. Also, the results have revealed a negative impact of the global financial crisis on the performance of banks.

Bryant (2016) has examined the Bank diversification and future stock price performance: evidence from Post-Acquisition returns after the GLBA. All acquisitions of commercial banks in the United States of other commercial banks, investment banks and insurance companies from 1999-2002 were identified. The final sample consisted of: (273) banks, (58) investment banks and (22) insurance companies. The study used the estimated efficiency factors and the measure of the efficiency of the profit of the bank and the variables included in the 
model of estimated profit efficiency, net revenues, net sale, the cost of sales and after - tax profit, non-operating expenses, as well as data on the various characteristics of the targeted and acquired assets, such as total assets, leverage, operating expenses, net sales, cash, cash flows, sales costs, non-operating expenses, return on assets and return on investment. The results showed banks that acquire investment banks and insurance companies are found to have an annual higher rate in risk-adjusted return than those acquire other banks.

Urhoghide and Ojeme (2016) have examined the effect of mergers and acquisitions on the determinants of dividends in Nigerian banks during the period 2007-2013. The determinants considered include liquidity, growth, financial leverage, profitability, company size and previous year's earnings. The results of the study revealed positive relationship between paid profits and the following variables: liquidity, return on assets, company size, previous year's earnings, and showed that the leverage and return on equity have a negative relationship on paid dividends.

Yeboah and Asirifi (2016) have studied the Effects of Mergers and Acquisitions on Operational Cost Efficiency of Banks in Ghana: A Case of Ecobank and Access Bank. Ghana has adopted a large-scale Mergers and acquisitions strategy in the banking sector. The financial data (2008-2012) for the two consolidated banks were used. and analyzed using percentage analysis of models used by bankers and other financial institutions in Ghana, and also used overall operational efficiency. The study concluded that mergers and acquisitions could provide a financing option for banks as well as promote them by improving costs.

The study of the Al-Qadi (2017) has dealt with the cases of mergers and acquisitions in general, with a focus on assessing the experience of some Arab countries, where the global economic and financial events led to the emergence of new concepts and trends in the economic arena, including banking mergers and acquisitions which are among the most important developments witnessed by the global financial services, especially during the last three decades. The study has revealed an important result that the Arab banking sector significantly needs banking mergers and acquisitions in light of the small size of banks and their inability to compete, and that their responses to the demands of financial globalization are still limited, in terms of number and value, and such responses were restricted on the ownership of small banks by large ones.

Kwenda et al. (2017) have examined the factors affecting the long-term performance of companies from Brazil, Russia, India, China and South Africa listed on BRICS, involved in cross-border mergers and acquisitions, by examining the performance of mergers, acquisitions and activities related to BRICS countries, and studying whether the BRICS countries make more use of acquisition than others. The accounting data, mergers and acquisitions information collected from Bloomberg online for the period (2000-2012) have been used. The results of the study have also revealed that (BRICS) companies participating in mergers and acquisitions processes continued to achieve profits, also, the size of the company significantly affects profits.

Ogada et al. (2017) have studied the impact of mergers and acquisitions strategies on the performance of the financial services sector in Kenya. The study has applied descriptive analysis, and included all the fifty one merged financial service institutions in Kenya which had completed their merger process by 31 December 2013. The preliminary data were obtained from the questionnaires. The study found that cost efficiency, synergy, board size and economic growth have an impact on performance, and diversification had no significant impact on financing.

Otieno and Kemunto (2017) have studied the impact of mergers and acquisitions on the financial performance of financial institutions in Kenya. The study relied on the descriptive approach using the event study to analyze the relationship between the ratios of EPS, ROE, EPS and ROA as a measure of financial performance to study the impact of mergers and acquisitions activities on the increase or decrease in financial performance. The study concluded that mergers and acquisitions positively affect the financial performance of commercial banks except for the negative return on shareholders' equity as attributed to the sole negative performance registered by the European Central Bank.

The current study has benefited from previous studies in enriching some theoretical aspects, covering them and taking advantage of some common aspects between this study and previous studies. Despite the importance of previous researches and studies, such studies carried out in the Jordanian environment, as far as the researcher knows, have dealt with the subject in terms of legal merger and consolidation but did not address the cases of "control" of holding companies over the subsidiaries they acquire. The current study aimed at identifying the effect of acquisition on income statement items in acquired company (subsidiary company), a case study of Irbid Electricity (IDECO). In order to achieve this objective, the researcher has carried out an analytical study that applied the descriptive analytical approach, using the necessary scientific knowledge on the different aspects of the study by reference to the previous studies and the scientific references, the use of the statistical approach to 
analyze the study data represented by the actual data taken from Irbid Electricity (IDECO) for the period (2002-2016).

\section{Literature Review}

\subsection{Acquisition}

Over the past three decades, companies have used acquisitions extensively as a strategic tool. This trend was initially limited to developed countries, especially the United States and the United Kingdom. The last decade of the $20^{\text {th }}$ century has witnessed a threefold increase in the number of acquisitions in the United States, and a fivefold increase in value has been reported (Malik et al., 2014). This trend has moved to other countries where competition among small and large companies worldwide has increased as a result of globalization. Acquisition is considered nowadays as one of the most important activities in the business world, often adopted by organizations to achieve objectives such as market competition, growth and preservation (Ashfaq et al., 2014). The acquisition is a company's takeover of another targeted company, which is lower in its financial, administrative viability (or both) than the holding company, by purchasing a proportion of its shares for controlling it (Alhayek, 2015). The acquired company is controlled by the acquisition of more than $50 \%$ of its net assets while each company preserves its legal entity (Al-Qadi, 2017), and then, there will be a holding company and a subsidiary company.This is called the control process, which is governed by various motives including expansion, or ensuring the continued flow of some raw materials from the subsidiary to the holding company (Dabbas, 2012). In practice, acquisition may be a hostile or friendly act. In a Friendly Takeover, the company's representatives negotiate with the shareholders of the acquired company over the purchase price, but in the case of the Hostile Takeover the shares of the targeted company are purchased without the approval of its management (Dahir, 2015), and acquired companies are classified as local or cross-border based on the region and nationality of the companies from different countries or economies (Ashfaq et al., 2014). The global economy has recently witnessed many voluntary businesses between strong companies to drive growth and revenues (Festus \& Richard, 2015). Legally, acquisition means buying a large percentage of the acquired company's shares or assets without the acquired company's losing of its legal entity (Dahir, 2015). The acquirer controls the management of the acquired company via its voting power in the acquired company's general assembly, because the general assembly is the authority that dominates the affairs of the company and appoints the members of its board of directors, and therefore, the acquirer has control in managing the affairs of the acquired company, so the most important characteristic of the acquisition is the control over the acquired company (Al-Qadi, 2017).

The Jordanian Companies Law No. (22) of 1997 as amended, has defined the holding company and the subsidiary company in Articles $(205,204)$ as follows: The Holding Company is a public joint stock company that financially and administratively controls other company or companies by owning more than half of its/their capital. The holding company may not own shares in partnership companies or Joint - stock company. The subsidiary may not own any share in the holding company. The holding company appoints its representatives on the board of directors of the subsidiary company based on its rate of contribution. Also, it is not entitled to participate in the election of the rest of the members of the board or the board of directors, as the case may be. Article (208) of the law requires the holding company to prepare consolidated financial statements at the end of each financial year and submit them to the general assembly along with explanations and data related thereto.

IFRS 10 requires the presentation of non-controlling interests in the consolidated financial position within equity and separately from the equity of the holding company. IFRS 10 considered the non-controlling interest is to be a source of financing from the owners and not an obligation.

IAS 27 provides for the existence of control when the parent company, directly or indirectly, owns more than half of the total voting rights of the acquired entity. The objective of this standard is to enhance the relevance, reliability and comparability of the information provided by the parent company in its separate and consolidated financial statements for a set of entities under its control. IAS 27 defines the circumstances under which another entity's financial statements (to be a subsidiary) are to be consolidated, the changes in equity of the subsidiary, and the loss of control of the subsidiary are accounted, and the acquisition of information that the entity must disclose in order to enable the users of the financial statements to assess the nature of the relationship between the entity and its subsidiaries. The consolidated financial statements are defined as the financial statements of the group that are presented as one economic entity, where the group represents the parent company and the subsidiary company. The abovementioned standard has defined the subsidiary company as an entity controlled by another entity (known as the parent company),and also, defined control as the power to govern the financial and operating policies of the entity in order to take advantage of its activities.

There are some points of difference that help determining whether a particular activity is a "merger" or an 
"acquisition". Merger is defined as an activity in which a company is merged into a company or two or more companies to form a completely new entity through the loss of their separate legal entities in a process known as called "Consolidation" (Ashfaq et al., 2014). In the case of an acquisition, it is a takeover of equity in another entity while the acquired entity preserves it independent legal entity. The acquirer company is known as the "parent company" and the acquired company is known as "the subsidiary company" (Ashfaq et al., 2014). Acquisition is the easiest and least risky form of investment, being easier and quicker than other ways of investment. (Alhayek, 2015).

Acquisition is one of business growth and expansion methods in order to increase the company's investments and activities and maximizing shareholders' wealth (Bryant, 2016), and to achieve financial, operational and strategic synergy (Ashfaq et al., 2014), to increase products, Rationalization of distribution channels and cost savings (Fasua \& Osagie, 2016). The growth has a positive relationship with profits because growth boosts profits and profits generating companies grow more and are able to survive in their markets (Kwenda et al., 2017). Also, acquisition leads at raising the acquired company's efficiency by implementing operational improvements, management and efficiency of existing branches (Yeboah \& Asirifi, 2016), and to benefit from financial globalization and information technology (Abdelaziz \& Bilel, 2012).

Although acquisitions have the potential to boost performance, reduce costs, expand market size, and improve competitiveness, among others, some fail. Failure is attributed to: weak strategic planning, communication difficulties, poor implementation, and cultural mismatch, and the big size of the investment in the target company (Yeboah \& Asirifi, 2016). The motives behind the acquisitions were divided into three main sections: (Festus \& Richard, 2015)

Strategic motive: This motive focuses on improving and developing business and is also linked to competitive advantage, access to emerging markets, and increased share.

Financial motive: It relates to maximizing the financial resources of the shareholders in the least risky investment, as the financial returns are the most important.

Administrative motive: This motive focuses on the managers' interests, but not necessary the shareholders' interest, in which case managers seek interests at the expense of shareholders.

\subsection{Income Statement}

It is one of the financial statements that must be prepared at the end of each financial period. It is a table of accounts for the financial results of a particular entity, summarizing the results and simplifying them, at the end of the financial period or in certain periods determined by the entity. The financial reports are considered to be the most important sources of information for decision makers (Safa, 2017) for the purpose of assessing the performance of companies and making decisions. Decision makers adopt a set of financial measures to judge the performance of companies (Al-Hilaiwi \& Sharif, 2017). Given the importance of the income statement for its users and its reliability in forecasting, future planning, and decision-making processes, management has to follow the means or procedures that allow it to improve its quality (Sabah, 2014).

The company's income statement is composed of the following components: energy sales for subscribers of all categories, the cost of purchasing energy from the IDECO and renewable sources of energy. Other operating revenues consist of installations fees, meters and workshop fees, power supply charges and replacement of meters. Revenues from non-core activities consist of revenues from waste collection, lighting maintenance, compensation, rental of buildings, revenues from renewable energy consultancy and other revenues. Administrative and general expenses related to administrative matters of the company consist of salaries, transfers and allowances of board members, stationery, maintenance expenses, vehicles expenses, mail and telephone expenses, cleaning and guard charges, etc. As for non-core activities, they represent expenses not directly related to the company's business, such as loss on disposal of property and equipment, cost of street lighting maintenance, cost of sale of damaged warehouse, donations and foreign currency losses (Irbid Electricity (IDECO), 2018).

\section{Method and Procedures}

\subsection{Study Population}

In order to achieve the objectives of the current study, the researcher has relied on the actual data extracted from the annual financial reports of Irbid Electricity (IDECO) for the years (2002-2016). Irbid Electricity (IDECO) is a limited public shareholding company incorporated in 1957 under the name "Irbid National Electricity Company" and its concession law was issued on under the name "Ajloun Power Company" in 1961, whereby the company has granted the right of the generation, transmission and distribution of electrical power to the entire 
concession area which includes the governorates of Irbid, Mafraq, Jerash, Ajloun and parts of Balqa Governorate. In the light of the administrative divisions that took place in the Kingdom in 1967, the company's name was changed to become Irbid Public Shareholding Electricity Company, with a total area of $(23,000)$ square kilometers representing (26\%) of the Kingdom's area. The holding Company (Electricity Distribution Company) (EDCO) has a total of $(4,436,800)$ shares of Irbid Electricity (IDECO) out of (8) million shares representing $(55.46 \%)$ of Irbid Electricity's shares (IDECO). The nominal value per share is one Jordanian dinar.

\subsection{Variables of the Study}

In order to achieve the objectives of the current study and to test the validity of its hypotheses, the study variables were classified and defined as follows: Independent variable: Acquisition, dependent variables: energy sales, energy purchase cost, other operating revenues, other revenues, operating expenses, other expenses, earning per share.

\subsection{Methodology of the Study}

The current study aimed at identifying the effect of acquisition on income statement items in acquired company (subsidiary company), a case study of Irbid Electricity (IDECO). In order to achieve this objective, the researcher has carried out an analytical study that applied the descriptive analytical approach, using the necessary scientific knowledge on the different aspects of the study by reference to the previous studies and the scientific references, the use of the statistical approach to analyze the study data represented by the actual data taken from Irbid Electricity (IDECO) for the period (2002-2016) using statistical descriptive methods including mean, standard deviation, maximum and minimumvalues, skewness, and kurtosis available on (E-Views) software before and after acquisition; also, change and rate of change among means and the effect of each variable.

\section{Analysis and Hypotheses Test}

This section deals with the analysis of the seven items of the study related to the revenues list of Irbid Electricity for seven years before the acquisition and seven years after the acquisition. The hypotheses will be tested using the (Paired Sample t-test).

The following table shows the results of the analysis of the items of the income statement of Irbid Electricity for seven years before and after the acquisition. The company was acquired in 2009. The following table shows the results of the analysis of variables.

Table 1. Analysis of the items of income statement before and after the acquisition and the means (figures in thousands of dinars)

\begin{tabular}{cccccccc}
\hline Year & $\begin{array}{c}\text { Energy } \\
\text { sales }\end{array}$ & $\begin{array}{c}\text { Energy } \\
\text { purchase cost }\end{array}$ & $\begin{array}{c}\text { Other operating } \\
\text { revenue }\end{array}$ & $\begin{array}{c}\text { Operating } \\
\text { expenses }\end{array}$ & Other revenue & $\begin{array}{c}\text { Other } \\
\text { expenses }\end{array}$ & $\begin{array}{c}\text { Earnings } \\
\text { per share }\end{array}$ \\
\hline Before $\boldsymbol{A}$ & & & & & & & \\
2002 & 42,987 & 35,763 & 2,357 & 7,246 & 108 & 1,341 & 0.229 \\
2003 & 44,569 & 38,396 & 2,852 & 7,425 & 225 & 1,263 & 0.115 \\
2004 & 48,734 & 42,228 & 2,935 & 7,857 & 305 & 971 & 0.124 \\
2005 & 51,667 & 45,371 & 3,048 & 8,455 & 249 & 563 & 0.116 \\
2006 & 57,986 & 49,536 & 2,980 & 9,983 & 167 & 514 & 0.215 \\
2007 & 64,374 & 55,073 & 3,170 & 10,779 & 209 & 182 & 0.370 \\
2008 & 84,751 & 71,243 & 3,562 & 13,664 & 1,216 & 258 & 0.899 \\
Average & $\mathbf{5 6 , 4 3 8}$ & $\mathbf{4 8 , 2 3 0}$ & $\mathbf{2 , 9 8 6}$ & $\mathbf{9 , 3 4 4}$ & $\mathbf{3 5 4}$ & $\mathbf{7 2 7}$ & $\mathbf{0 . 2 9 5}$ \\
\hline After $\boldsymbol{A}$ & & & & & & & \\
2010 & 112,760 & 91,612 & 2,821 & 16,808 & 2,697 & 948 & 1.914 \\
2011 & 131,443 & 112,877 & 2,519 & 18,027 & 2,253 & 337 & 1.052 \\
2012 & 150,154 & 123,469 & 1,774 & 20,019 & 3,580 & 1,508 & 1.131 \\
2013 & 171,689 & 150,565 & 2,449 & 20,863 & 3,688 & 2,385 & 0.425 \\
2014 & 213,207 & 186,087 & 2,356 & 22,404 & 5,558 & 4,991 & 0.815 \\
2015 & 238,306 & 212,692 & 2,121 & 24,433 & 6,022 & 5,163 & 0.419 \\
2016 & 251,591 & 214,511 & 1,585 & 27,868 & 8,539 & 7,767 & 1.690 \\
\hline Average & $\mathbf{1 8 1 , 3 0 7}$ & $\mathbf{1 5 5 , 9 7 3}$ & $\mathbf{2 , 2 3 2}$ & $\mathbf{2 1 , 4 8 9}$ & $\mathbf{4 , 6 2 0}$ & $\mathbf{3 , 3 0 0}$ & $\mathbf{1 . 0 6 5}$ \\
\hline
\end{tabular}

The above table shows that the acquisition of Irbid Electricity has had a positive effect on the overall results of the company's activities as follows: 
The value of energy sales achieved a significant increase after the acquisition, rising from an average of $(56,438)$ before the acquisition to $(181,307)$ after the acquisition which is a good rise. This shows a significant improvement in the company's position and will positively affect the profitability indicators. The researcher attributed this increase due to the nature of the service provided by the electricity company and the expansion of service provision.

As for energy purchase cost, it accompanied the higher rates of increase in sales. It is normal that the increase in sales will be accompanied by an increase in the direct costs of energy costs. The average increase was from $(48,230)$ before acquisition to $(155,973)$ after acquisition. The cost ratios were lower than the increase in sales revenues which is a positive indicator of the acquisition and indicates that the performance of the company has improved, which will reflect positively on the profitability and market share of the company.

In terms of revenues, it was found that other operating revenues decreased as a result of the acquisition at average from $(2,986)$ before the acquisition to $(2,232)$ after the acquisition. This may reflect that the company has relied after acquisition on core activities of the company rather than relying on non-core activities, Despite the fact that other revenues increased significantly from (354 thousand JDs) before the acquisition to (4,620 thousand JDs) after the acquisition, which is a good indicator of the company's profitability.

The increase in operating expenses and other expenses markedly increased with the increase in energy sales which increased at average from (9344 and727) before the acquisition to (21489 and 3,300) respectively, after the acquisition, and it is normal that higher sales are accompanied by higher costs.

Earnings per share increased as a result of the strong improvement in the earnings per share index, which rose on average from (0.295 JD) per share before the acquisition to (1.064) after the acquisition. The index for all years after the acquisition was better than the years before the acquisition. Thus is a good indicator for the increase of book and market value of the company's shares.

\subsection{Descriptive Analysis}

Table 2 shows the results of descriptive analysis of the study variables, using statistical descriptive methods including mean, standard deviation, maximum and minimum values, skewness, and kurtosis available on (E-Views) software before and after acquisition; also , change and rate of change among means and the effect of each variable.

The results indicated that the values of (skewness) of the study variables were within the acceptable natural range of the skewness coefficients where the values were limited between \pm 1 and that the kurtosis behavior of the study variables was greater than the natural distribution (kurtosis $=3$ ), where this test was carried out to verify that the data are distributed naturally. Knowing whether data were naturally distributed or not involves selecting the appropriate statistical method to test hypotheses. Most tests require data to be naturally distributed. In order to achieve this, - Jarque-Bera test was used ,where it was found that the probability of testing all model variables were higher than (5\%), which means data are about the natural distribution.

Table 2. Descriptive analysis of the study variables

\begin{tabular}{|c|c|c|c|c|c|c|c|}
\hline Variable & $\begin{array}{c}\text { Energy } \\
\text { sales }\end{array}$ & $\begin{array}{c}\text { Energy } \\
\text { purchase cost }\end{array}$ & $\begin{array}{c}\text { Other operating } \\
\text { revenue }\end{array}$ & $\begin{array}{c}\text { Operating } \\
\text { expenses }\end{array}$ & $\begin{array}{c}\text { Other } \\
\text { revenue }\end{array}$ & $\begin{array}{c}\text { Other } \\
\text { expenses }\end{array}$ & $\begin{array}{c}\text { Earnings per } \\
\text { share }\end{array}$ \\
\hline \multicolumn{8}{|c|}{ Before Acquisition } \\
\hline Mean & $56,438.29$ & $48,230.00$ & $2,986.29$ & $9,344.14$ & 354.14 & 727.43 & 0.295 \\
\hline Median & 51,667 & 45,371 & 2,980 & 8,455 & 225 & 563 & 0.215 \\
\hline Max. & 84,751 & 71,243 & 3,562 & 13,664 & 1,216 & 1,341 & 0.899 \\
\hline Min. & 42,987 & 35,763 & 2,357 & 7,246 & 108 & 182 & 0.115 \\
\hline Std. & 14554.03 & 12072.43 & 361.87 & 2317.17 & 385.06 & 467.81 & 0.281 \\
\hline Skewness & 1.081 & 0.959 & -0.207 & 0.919 & 0.930 & 0.209 & 0.639 \\
\hline Kurtosis & 3.047 & 3.906 & 3.040 & 3.637 & 4.930 & 3.491 & 4.214 \\
\hline Jarque-Bera & 1.366 & 1.077 & 0.020 & 1.024 & 5.435 & 0.714 & 3.566 \\
\hline Probability & 0.505 & 0.583 & 0.975 & 0.599 & 0.066 & 0.699 & 0.168 \\
\hline \multicolumn{8}{|c|}{ After Acquisition } \\
\hline Mean & $181,307.14$ & $155,973.29$ & $2,232.14$ & $21,488.8$ & $4,619.57$ & $3,299.86$ & 1.064 \\
\hline Median & 171,689 & 150,565 & 2,356 & 20,863 & 3,688 & 2,385 & 1.052 \\
\hline Max. & 251,591 & 214,511 & 2,821 & 27,868 & 8,539 & 7,767 & 1.914 \\
\hline Min. & 112,760 & 91,612 & 1,585 & 16,808 & 2,253 & 337 & 0.419 \\
\hline Std. & 53935.86 & 49389.53 & 434.44 & 3800.13 & 2215.66 & 2727.76 & 0.578 \\
\hline
\end{tabular}




\begin{tabular}{cccccccc}
\hline Skewness & 0.100 & 0.043 & -0.282 & 0.454 & 0.686 & 0.487 & 0.295 \\
Kurtosis & 3.498 & 3.458 & 3.905 & 4.200 & 4.320 & 3.886 & 3.774 \\
Jarque-Bera & 0.669 & 0.695 & 0.442 & 0.426 & 0.685 & 0.638 & 0.539 \\
Probability & 0.715 & 0.706 & 0.801 & 0.807 & 0.709 & 0.726 & 0.763 \\
Average change & $124,868.85$ & $107,743.29$ & -754.15 & $12,144.66$ & $4,265.43$ & $2,572.43$ & 0.769 \\
\%change & 2.212 & 2.234 & -0.253 & 1.300 & 12.044 & 3.536 & 2.607 \\
Effect & positive & positive & Negative & positive & positive & positive & positive \\
\hline
\end{tabular}

The results of the descriptive analysis of the variables of the study indicate that all the changes means of variables were positive after the acquisition with acceptable means, except for the "other operating revenues" where the mean of change was negative.

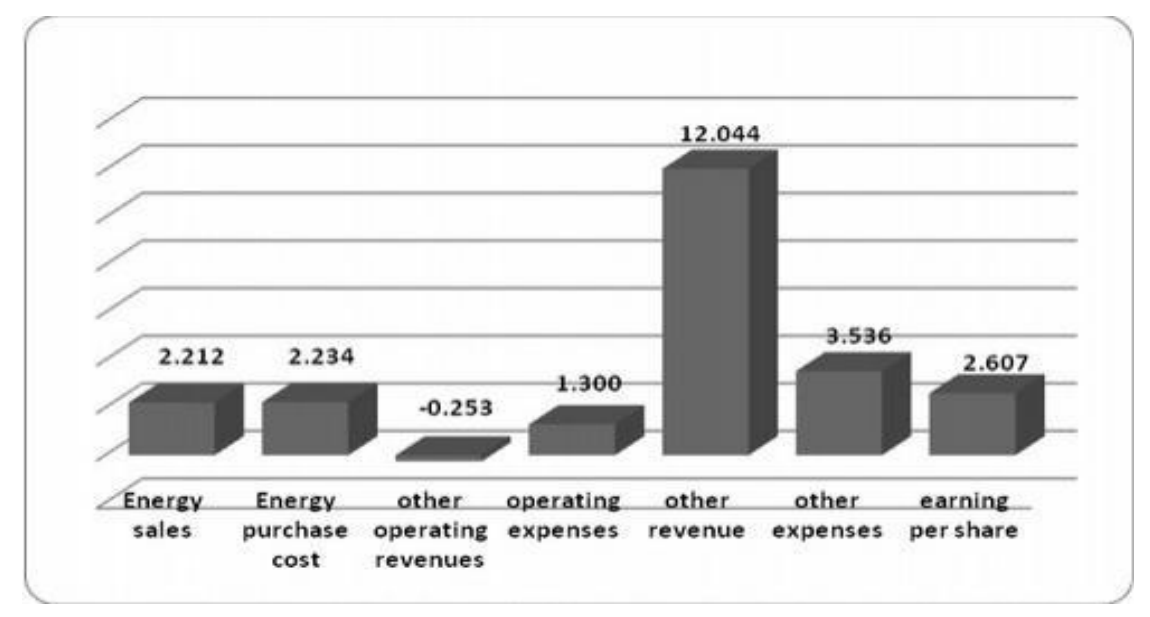

\section{Results}

Paired Sample t-test is used to identify the difference between the mean before the event and after the event for the same case, and this applies exactly to the subject of the study, which aims to identify the difference between the means of the variables before and after the acquisition of the same study variables.

Table 3 shows the results of the Paired Sample t-test to identify whether there are statistically significant differences between the mean of each variable used in the study before the acquisition and after the acquisition.

Table 3. Results of Paired sample T-test

\begin{tabular}{ccccc}
\hline Item & $\begin{array}{c}\text { Average difference } \\
\text { before- after }\end{array}$ & $\begin{array}{c}\text { Standard } \\
\text { deviation }\end{array}$ & T & $\begin{array}{c}\text { Significance } \\
\text { level T }\end{array}$ \\
\hline Energy sales (before- after) & -124868.857 & 41114.728 & -8.035 & 0.000 \\
Energy purchase cost (before- after) & -107743.286 & 38918.169 & -7.325 & 0.000 \\
Other operating revenue (before- after) & 754.143 & 758.298 & 2.631 & 0.039 \\
Operating expenses (before- after) & -12144.714 & 1618.381 & -19.854 & 0.000 \\
Other revenue (before- after) & -4265.429 & 1936.107 & -5.829 & 0.001 \\
Other expenses (before- after) & $\mathbf{- 2 5 7 2 . 4 2 9}$ & $\mathbf{3 1 5 0 . 0 5 9}$ & $\mathbf{- 2 . 1 6 1}$ & $\mathbf{0 . 0 7 4}$ \\
Earnings per share (before- after) & -0.768 & 0.530 & -3.838 & 0.009 \\
\hline
\end{tabular}

It is noted from the table that:

There were statistically significant differences between the means of energy sales before and after acquisition at a significance level of $(0 \%)$, which is less than the significance level $(5 \%)$. The value before acquisition was less than it after the acquisition equivalent to $(124868,857)$, and this means that acquisition has enhanced energy sales.

There were significant differences between the means of cost of energy purchase before acquisition and after acquisition at a significance level of $(0 \%)$, which is less than significance level $(5 \%)$. The value before the acquisition was less than it after the acquisition equivalent to (107743.286) and this means that acquisition has enhanced energy purchase cost as a result of the acquisition. 
The results showed that there were statistically significant differences between the means of operating revenues before and after the acquisition at a significance level of (3.9\%), respectively, which is less than the significance level $(5 \%)$. The value of the mean before the acquisition for operating revenues was greater than it after the acquisition, equivalent to (754.143), indicating that the acquisition has improved the operating revenues of the company.

There were significant differences between the means of operating expenses before and after the acquisition at a significance level of $(0 \%)$, which is less than the significance level $(5 \%)$. The value before the acquisition was less than it after the acquisition equivalent to (12144.714) and this means that operating expenses have increased as a result of the acquisition.

The results showed that there were statistically significant differences between the means of other revenues before and after the acquisition at a significance level of $(0.01 \%)$, respectively, which is less than the significance level (5\%). The value of the means of other revenues before and after the acquisition was less than it after the acquisition, equivalent to (4265.429) and this means that the acquisition has improved the other revenues of the company.

There were statistically significant differences (5\%) between the average of earnings per share before and after it, as it was before the acquisition less than it after the acquisition (0.768). This means that asset value per share has improved as a result of the acquisition.

The results showed no statistically significant differences between the means of the other expenses before the acquisition and the average of the other expenses after the acquisition. The values were not statistically significant at the significance level. This means that acquisition was not statistically significant in improving this variable.

\section{Conclusions \& Recommendations}

\subsection{Conclusion}

The current study aimed at identifying the effect of acquisition on income statement items in acquired company (subsidiary company), a case study of Irbid Electricity (IDECO). In order to achieve this objective, the researcher has carried out an analytical study that applied the descriptive analytical approach, using the necessary scientific knowledge on the different aspects of the study by reference to the previous studies and the scientific references, the use of the statistical approach to analyze the study data represented by the actual data taken from Irbid Electricity (IDECO) for the period 2002-2016.

The results of the study have revealed the validity of $\mathrm{H} 0$ which states "There is an effect of acquisition on income statement items in acquired company (subsidiary company), a case study of Irbid Electricity (IDECO).

There were statistically significant differences in energy sales average, energy purchase cost, other operating revenues, other revenues, operating expenses, and earning per share before and after acquisition, and also, the results have shown no significant differences between the average of other expenses before and after acquisition.

\subsection{Recommendations}

Adopting proper planning and carrying out detailed studies on the reality of the companies to be controlled and the nature of their operational performance, noting the economic conditions witnessed by the country.

Taking advantage of the success of acquisitions and thinking seriously of them for long-term investment.

Raising awareness of the importance of acquisition as a long-term investment and to clarify its positive effects.

Taking advantage of global experiences in acquisitions and their positive impact.

Adopting acquisition as a strategy to increase investments and develop the management of acquired companies.

Carrying out further studies on the acquisition of public shareholding companies in different sectors to identify the impact of acquisition in other sectors.

\section{References}

Abdelaziz, H., \& Bilel, K. (2012). Can bank mergers and acquisitions favour the credit availability for Tunisian firms? International Journal of Business and Management, $7(15), 61$. https://doi.org/10.5539/ijbm.v7n15p61

Akinbuli, S., \& Kelilume, I. (2013). The effects of mergers and acquisition on corporate growth and profitability: Evidence from Nigeria. Global Journal of Business Research, 7(1).

Al-Hayek, M. A. (2015). The impact of merger operations between Jordanian Corporations in their Stocks. PHD 
thesis, University of Damascus, Accounting Department.

Al-Hilaiwi, A. K., \& Al-Sharif, A. (2017). The Importance of Financial Ratios Derived from the Income and the Financial Position Statments for Forecasting Financial Failure in General Industrial Companies in Libya. Al Manarah, 23(2).

Al-Qadi, N. F. R. A. (2017). Banking merger and acquisitions in Arab countries. Journal of Administrative Sciences, Periodic Scientific Journal, (1).

Ashfaq, K., Usman, M., Hanif, Z., \&Yousaf, T. (2014). Investigating the impact of merger \& acquisition on post-merger financial performance (Relative \& absolute) of companies (Evidence from non-financial sector of Pakistan). Research Journal of Finance and Accounting, 5(13), 88-102. https://doi.org/10.6007/IJARBSS/v4-i11/1307

Bryant, L. L. (2016). Bank Diversification and Future Stock Price Performance: Evidence from Post-Acquisition Returns after the GLBA. Accounting and Finance Research, 5(1), 137. https://doi.org/10.5430/afr.v5n1p137

Dabbas, M. M. (2012). The impact of the merger on the performance of companies and their profits. Journal of the Islamic University for Economic and Administrative Studies, 20(2).

Dahir, H. (2015). The impact of Merger and Acquisition on the Bank's Financial Performance -Case Study: Audi Saradar Banking Group for Private Services. Economic and Legal Sciences Series, 37(3).

Fasua, H. K., \& Osagie, O. (2016). Proactive Merger and Acquisition and Firm Performance. Research Journal of Finance and Accounting, 7(14).

Fcib, N. O. (2013). Impact of pre and post bank consolidation on the growth of Nigeria economy. International Journal of Business and Management, 8(13). https://doi.org/10.5539/ijbm.v8n13p73

Festus, O., \& Richard, E. O. (2015). Impact of Merger and Acquisition on the Growth of Nigerian Banking Industry. Research Journal of Finance and Accounting.

International Accounting Standard Board (IASB).Retrieved from http://www.iasb www.ifrs.org

International Financial Report Standards (IFRS). Retrieved from http://www.ifrs.org

Irbid Electricity. Retrieved from https://www.ideco.com.jo

Joo-hyun, L., \& Jin-ho, C. (2017). Earnings Management of Mergers and Acquisitions of Target Candidates and Deal Withdrawn. Journal of Applied Business Research, 33(3), 467. https://doi.org/10.19030/jabr.v33i3.9937

Jordanian Companies Law No. (22) of 1997 as amended.

Kwazhi, J. W., \& Kumshe, A. M. (2015). Effects of Mergers and Acquisitions on Dividend Payment and Share Prices of Selected Deposit Money Banks in Nigeria. Research Journal of Finance and Accounting, 6(18).

Kwenda, F., Oyetade, D., \& Dobreva, R. (2017). Factors affecting the Long-Term Post-Acquisition Performance of BRICS firms engaging in Cross-Border Mergers and Acquisitions. Acta Universitatis Danubius. CEconomica, 13(2).

Malik, M. F., Anuar, M. A., Khan, S., \& Khan, F. (2014). Mergers and acquisitions: A conceptual review. International Journal of Accounting and Financial Reporting, 4(2), 520. https://doi.org/10.5296/ijafr.v4i2.6623

Ogada, A., Achoki, G., \& Njuguna, A. (2017). Effect of Mergers and Acquisitions Strategies on Financial Performance of Financial Services Sector. International Journal of Finance, 1(1), 18-37.

Otieno, O. D., \& Kemunto, S. L. (2017). Effect of Mergers and Acquisitions on the Financial Performance of Commercial Banks in Kenya. Research Journal of Finance and Accounting 2 8(14).

Sabah, B. N. (2014). The role of auditing in improving the income statement. A sample of the reports of auditors of Wadi province for the period 2010-2012 (Doctoral dissertation).

Safa. (2017). The extent to which companies listed on the Damascus Securities Exchange (DSM) are required to disclose in accordance with the requirements of IFRS 8 For Operating Sectors. An Applied Study. Economic and Legal Sciences Series, 38(3).

Shibil, S. O., \& Jaradat, Z. A. (2014). The extent to which administrative accounting contributes to the merger of commercial banks. Al-Manara Journal for Research and Studies, Al-Bayt University, 19(4).

Urhoghide, R. O., \& Ojeme, S. S. (2016). Effect of Mergers and Acquisitions on the Determinants of Dividend 
Payout in Nigeria. Search Journal of Finance and Accounting, 7(2).

Xiang, M. Y. (2017). The Valuation Research of Steel Industry Enterprise in Mergers and Acquisitions. Management Science and Engineering, 11(1), 94-100.

Yeboah, J., \& Asirifi, E. K. (2016). Mergers and Acquisitions on Operational Cost Efficiency of Banks in Ghana: A Case of Ecobank and Access Bank. International Journal of Business and Management, 11(6), 241. https://doi.org/10.5539/ijbm.v11n6p241

\section{Copyrights}

Copyright for this article is retained by the author(s), with first publication rights granted to the journal.

This is an open-access article distributed under the terms and conditions of the Creative Commons Attribution license (http://creativecommons.org/licenses/by/4.0/). 